\title{
3D restoration of a Cretaceous rift basin in Kilen, eastern North Greenland
}

\author{
Kristian Svennevig ${ }^{1,2}$, Pierpaolo Guarnieri' \& Lars Stemmerik ${ }^{2,3}$
}

\author{
${ }^{1}$ Geological Survey of Denmark and Greenland (GEUS), Øster Voldgade 10, 1350 Copenhagen, Denmark. \\ 2Natural History Museum of Denmark, University of Copenhagen, Øster Voldgade 5-7, 1350 Copenhagen, Denmark. \\ ${ }^{3}$ University Centre in Svalbard, P.O. Box 156, N-9171 Longyearbyen, Norway. \\ E-mail corresponding author (Kristian Svennevig): ksv@geus.dk
}

The semi-nunatak Kilen is a key area to understand the setting of the Cretaceous sedimentary basin in eastern North Greenland. The basin geometry has been obscured by later N-S compression and inversion of presumable Palaeocene-Eocene age. A 3D restoration of the Cretaceous basin is presented based on new oblique photogrammetry and field data combined with published data. The 3D restoration focuses on the main faults and a well constrained mid-Cretaceous horizon. The restoration shows that the horizon was offset down-to-the-ENE by several NNW-SSE-striking normal faults and highlights the similarity of the pre-folding basin to a normal rifted margin. The northwestern part of the restored area comprises five fault blocks divided by four NNW-SSE-striking normal faults dipping to the ENE, whereas the southeastern part consists of a single large fault block deformed by minor antithetic faulting. Minimum offsets on exposed normal faults are between 780 and $1200 \mathrm{~m}$, and the fault blocks are between 1.5 and more than $10 \mathrm{~km}$ in width. The restoration and interpretation of the Cretaceous basin at Kilen as extensional opens for a similar interpretation for NNW-SSE-oriented faults affecting Mesozoic sediments elsewhere in the Wandel Sea Basin which were previously interpreted as having formed in a strike-slip setting. The basin restored at Kilen has several similarities to basins on the southwestern Barents Sea margin, especially the Bjørnøya Basin, located just 100-200 km east of Kilen in pre-North Atlantic opening times. The two basins were separated by the Stappen High and the basin at Kilen could be the western part of a successful rift that eventually resulted in the opening of the North Atlantic.

Keywords: Arctic, North Greenland, Wandel Sea Basin, Barents Sea, Cretaceous, Rifting

Electronic Supplement: 3D models of Kilen

Received 23. November 2016 / Accepted 24. January 2017 / Published online 15. March 2017

\section{Introduction}

The Mesozoic structural evolution of the Wandel Sea Basin in eastern North Greenland has for a long time been regarded as a product of mid-Cretaceous transtension and deposition in isolated pull-apart basins (Håkansson \& Pedersen, 1982, 2001, 2015; Pedersen, 1988; Håkansson \& Stemmerik, 1989). This tectonic phase was named the "mid Cretaceous Kilen Event" by Pedersen (1988).
The semi-nunatak Kilen in the eastern part of the Wandel Sea Basin is a key area to understand the Mesozoic basin evolution since it has the most complete Mesozoic sedimentary succession in the basin. According to Håkansson \& Pedersen (1982, 2015), Mesozoic deposition on Kilen was controlled by dextral transtension resulting in the formation of several pull-apart basins culminating in end-Cretaceous transpression. Recently, Svennevig et al. (2016a) presented an alternative structural interpretation of 
Kilen suggesting that the area was rather subjected to a phase of post-Coniacian ENE-WSW extension followed by $\mathrm{N}-\mathrm{S}$ compression of possibly Palaeocene-Eocene age. This structural model allows for a new and simpler view of the Mesozoic Wandel Sea Basin as a rift basin dominated by extensional faults; in line with basins along the conjugate southwestern Barents Sea margin such as the Bjørnøya, Sørvestnaget and Tromsø basins (Faleide et al., 2008; Gernigon et al., 2014).

This paper explores the implications of this new tectonic model for Mesozoic basin evolution by presenting a pre-folding $3 \mathrm{D}$ reconstruction of the basin at Kilen using the structural model of Svennevig et al. (2016a). The reconstruction focuses on the main faults and uses a single, well constrained, mid-Cretaceous horizon as a marker. While the emphasis is on restoration of the Kilen basin, the results may have broader implications for Mesozoic sedimentation elsewhere in the Wandel Sea Basin and further examination of the Mesozoic evolution of eastern North Greenland is needed in order to better understand this part of the De Geer Zone.

\section{Geological setting}

The Carboniferous to Palaeogene Wandel Sea Basin (Dawes \& Soper, 1973) in eastern North Greenland stretches from Kap Washington in northernmost
Greenland to Holm Land along the east coast (Fig. 1; Håkansson et al., 1981; Håkansson \& Stemmerik, 1989), and shares a common geological history with basins in Arctic Canada, Svalbard and the western Barents Sea (Soper et al., 1982; Håkansson \& Stemmerik, 1989; Piepjohn \& von Gosen, 2001; Gosen \& Piepjohn, 2003; Stemmerik \& Worsley, 2005; Piepjohn et al., 2015, 2016).

Sediments of the Wandel Sea basin rest on ProterozoicSilurian rocks deformed during the Ellesmerian and Caledonian orogenies (Surlyk, 1991). Deposition was controlled by three major structural elements: the Harder Fjord Fault Zone to the north, the Trolle Land Fault Zone and the East Greenland Fault Zone to the south (Fig. 1; Håkansson \& Stemmerik, 1989). The Trolle Land Fault Zone in eastern Peary Land is the southwesternmost of a series of at least five, 7-10 km-spaced, NNW-SSEstriking faults forming the Trolle Land Fault System (ZinkJørgensen, 1994; Zink-Jørgensen \& Håkansson, 1994). It initiated during the Late Carboniferous (Stemmerik et al., 1996) and is believed to continue to Amdrup Land in the southeast where faults of similar orientation have been mapped (Fig. 1; Håkansson \& Stemmerik, 1989; Stemmerik et al., 2000). In pre-Atlantic opening times, these faults were parallel to the Billefjorden and Lomfjorden fault zones on the conjugate Svalbard margin (Soper et al., 1982; Håkansson \& Stemmerik, 1989; Stemmerik \& Håkansson, 1991; Faleide et al., 1993; Piepjohn \& von Gosen, 2001; Gosen \& Piepjohn, 2003; Leever et al., 2011).

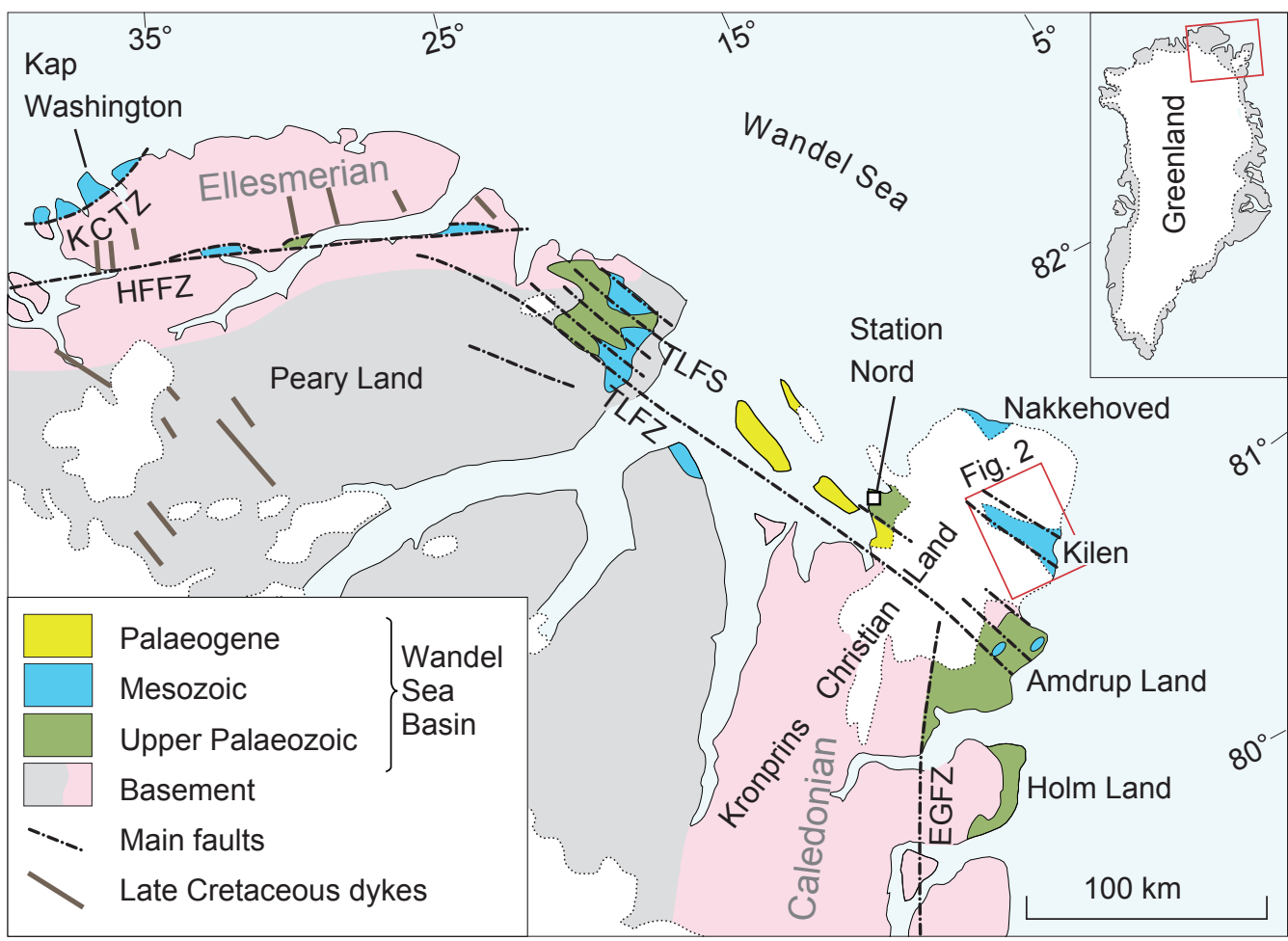

Figure 1. Simplified geology of the Wandel Sea Basin showing the major structural elements and the distribution of Upper Palaeozoic to Palaeogene sedimentary rocks. Modified from Håkansson \& Stemmerik (1989) and Stemmerik et al. (2000) with schematic faults from Kilen modified from Svennevig et al. (2016a). Dykes are simplified from Bengaard \& Henriksen (1984). Abbreviations: KCTZ - Kap Cannon Thrust Zone, TLFZ - Trolle Land Fault Zone, TLFS - Trolle Land Fault System, EGFZ - East Greenland Fault Zone, HFFZ - Harder Fjord Fault Zone. 
Upper Carboniferous-Triassic deposition took place in a fairly simple system of grabens and half-grabens referred to as the North Greenland-Svalbard Rift Basin (Håkansson \& Stemmerik, 1989; Stemmerik \& Håkansson, 1989, 1991). In contrast, the JurassicCretaceous basin evolution is regarded as more complex due to tectonic overprinting and difficulty in correlating scattered outcrops (Håkansson et al., 1991). Håkansson \& Stemmerik (1989) suggested that all Upper Jurassic and Cretaceous sediments were deposited in basins formed by strike-slip tectonics and transtension in the "Wandel Hav strike-slip mobile belt" (WHSSMB) of Håkansson \& Pedersen (1982). Recently, Håkansson \& Pedersen (2015) further extended this structural regime back into Late Permian times and suggested six generations of transtension resulting in twenty Late Permian-Late Cretaceous pull-apart basins exposed across the Wandel Sea Basin. Soper \& Higgins (1991) challenged the existence of the WHSSMB since no substantial strikeslip has been demonstrated along faults in the Wandel Sea Basin, and Gosen \& Piepjohn (2003) did not find any structural evidence for Jurassic and Late Cretaceous strike-slip deformation and pull-apart basins.

The Jurassic-Cretaceous succession includes Upper Jurassic (Oxfordian) - Lower Cretaceous (Valanginian) sedimentary rocks both in eastern Peary Land and at Kilen (Håkansson et al., 1991). The succession is thicker, stratigraphically more complete and generally composed of deeper-water facies at Kilen as compared to eastern Peary Land (Håkansson et al., 1991; Dypvik et al., 2002). Lower Cretaceous (Aptian-Albian) marine deposits are mainly preserved at Kilen with small down-faulted outliers in the northwest part of the basin (Håkansson et al., 1991). Upper Cretaceous strata occur in scattered outcrops across the basin with the thickest and most complete succession at Kilen (Håkansson et al., 1991).

Late compressive deformation in the Wandel Sea Basin has been debated and referred to transpressive dextral strike-slip movements by Håkansson \& Pedersen (1982, 2001, 2015), Pedersen \& Håkansson (1999), Gosen \& Piepjohn (2003) \& Piepjohn et al. $(2015,2016)$ whereas Soper et al. (1982), Soper \& Higgins (1991), Lyberis \& Manby (1999), Manby \& Lyberis (2000) and Guarnieri (2015) have suggested pure compression. The proposed age of deformation ranges from pre-opening Late Cretaceous - earliest Palaeocene (Håkansson \& Pedersen, 1982; Håkansson, 1988; Pedersen \& Håkansson, 1999; Manby \& Lyberis, 2000; Guarnieri, 2015) to PalaeoceneEocene (Soper et al., 1982; Soper \& Higgins, 1991; Gosen \& Piepjohn, 2003).

\section{Kilen}

The more than 3000 m-thick succession of Mesozoic siliciclastics at Kilen is faulted and folded, and the poor quality of the outcrops over large areas makes correlation difficult (Fig. 2; Håkansson et al., 1993, 1994a; Svennevig et al., 2016a). Initial mapping and dating of key units resulted in the recognition of 23 lithostratigraphic units of Jurassic-Cretaceous age and an Upper Palaeozoic mélange unit (Pedersen, 1989; Håkansson et al., 1993, 1994a). More recent fieldwork by the Geological Survey of Denmark and Greenland (GEUS) (Bojesen-Koefoed et al., 2014) has indicated the need for a stratigraphic revision and a more simplified stratigraphic scheme is applied here to divide the succession into five units cf., Svennevig et al. (2016a) (Fig. 3). The presence of thick Upper Palaeozoic deposits below the Mesozoic strata is inferred based on the occurrence of the tentatively dated, Carboniferous gypsum mélange unit in central-west Kilen (Håkansson et al., 1993) exposed in the core of an anticline (Svennevig et al., 2016a, b), and the presence of thick Upper Palaeozoic deposits to the northwest at Station Nord and in the southwest at Amdrup Land (Stemmerik et al., 1996).

Håkansson \& Pedersen (2015) view the structural evolution of Kilen as dominated by three transtensional phases resulting in five local pull-apart basins. Their "Ingeborg Event" (Pedersen, 1988) is only indirectly detected as a structural background to the Jurassic basin formation. The Aptian-Albian "Ghost event 2" is inferred by the presence of strata of this age, whereas the Cenomanian-Turonian "Kilen Event" (Pedersen, 1988) is based on the observation of mesoscale normal faults and the interpretation of subvertical strikeslip faults bordering Upper Cretaceous sedimentary rocks. Post-depositional compression was interpreted to be transpressive and dominated by strike-slip faults (Håkansson et al., 1993; Pedersen \& Håkansson, 1999; Gosen \& Piepjohn, 2003).

An alternative model for Kilen is presented here based on mapping from oblique photogrammetry combined with 3D modelling, fieldwork and integration of previous data (Svennevig et al., 2016a). In this model, a series of NNWSSE-trending normal faults is interpreted to be the result of post-Coniacian ENE-WSW extension (D1) followed by N-S compression of possibly Palaeocene-Eocene age (D2), folding the faults passively (Figs. $2 \& 4$; Table 1). In Kilen Fjelde, two thrust sheets were recognised belonging to the D2 phase: the upper Hondal Elv Thrust Sheet comprises mainly Upper Cretaceous strata whereas the lower Kilen Thrust Sheet includes Carboniferous to Upper Cretaceous strata (Figs. 2 \& 4). The thrust sheets are separated by a subhorizontal detachment fault, the Central Detachment (CD, Fig. 2). The younger on older relationship across the Central Detachment is interpreted to reflect basin inversion and presence of an unexposed D1 normal fault to the northeast (NN, Fig. 2; Svennevig et al., 2016a). D1 structures include three NNW-SSEstriking down-to-the-ENE normal faults (I-III, Fig. 2). On Gåseslette, a single frontal thrust and three back thrusts called the Gåseslette Thrusts (GT) are associated with the D2 phase (Figs. 2 \& 4). D1 structures include 


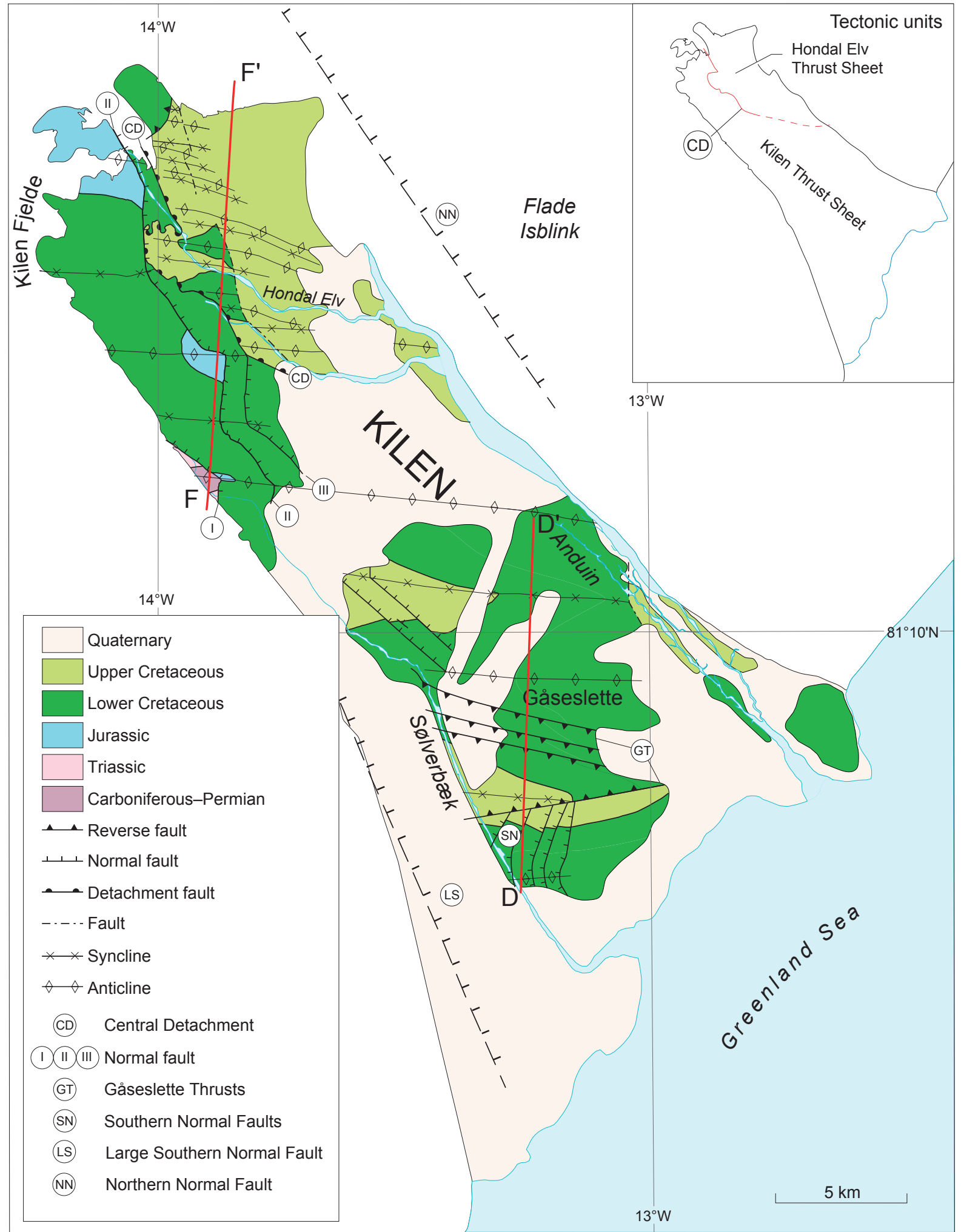

Figure 2. Simplified geological map of Kilen highlighting the Upper and Lower Cretaceous strata and main faults. The extents of the Kilen and Hondal Elv Thrust Sheets are shown in the inset map. The traces of cross-sections F-F' and D-D' in Fig. 4 are shown. Modified from Svennevig et al. $(2016 a, b)$. The map is also shown in the 3D model in the Electronic Supplement.

a series of minor antithetic normal faults called the Southern Normal Faults (SN), indicating the presence of a larger, unexposed normal fault to the southwest (LS; Svennevig et al., 2016b).

\section{D modelling}

The compressional structures (D2) have been restored through 3D modelling to examine the architecture resulting from the extensional phase (D1). The 
A

\begin{tabular}{|l|l|c|}
\hline \multirow{2}{*}{ Age } & \multicolumn{2}{c|}{ Kilen Fjelde } \\
\cline { 2 - 3 } & $\begin{array}{c}\text { Units (Svennevig } \\
\text { ef al., 2016a) }\end{array}$ & Thickness \\
\hline Upper Cretaceous & Undifferentiated & 700 (min) \\
\hline Lower Cretaceous & $\begin{array}{l}\text { Hondal, } \\
\text { Galadriel Fjeld, } \\
\text { Lichenryg, } \\
\text { Dromledome }\end{array}$ & 1570 (min) \\
\hline Jurassic & Undifferentiated & 500 (min) \\
\hline Triassic & Undifferentiated & 300 (min) \\
\hline $\begin{array}{l}\text { Carboniferous - } \\
\text { Permian }\end{array}$ & Undifferentiated & 20 (min) \\
\hline
\end{tabular}

B

\begin{tabular}{|c|c|c|}
\hline \multirow[b]{2}{*}{ Age } & \multicolumn{2}{|c|}{ Gåseslette } \\
\hline & $\begin{array}{c}\text { Units (Svennevig } \\
\text { et al., 2016a) }\end{array}$ & Thickness \\
\hline Upper Cretaceous & Sølverbæk & 600 (min) \\
\hline Lower Cretaceous & $\begin{array}{l}\text { Kangoq Ryg } \\
\text { Tågekyst }\end{array}$ & 1450 (min) \\
\hline
\end{tabular}

Figure 3. Overview of the informal lithostratigraphical units of Kilen Fjelde (A) and Gåseslette (B). The thicknesses in metres are from Svennevig et al. (2016a); ages are from Håkansson et al. (1993, 1994a), Dypvik et al. (2002) and Alsen et al. (2017). Modified from Svennevig et al. (2016a).

S

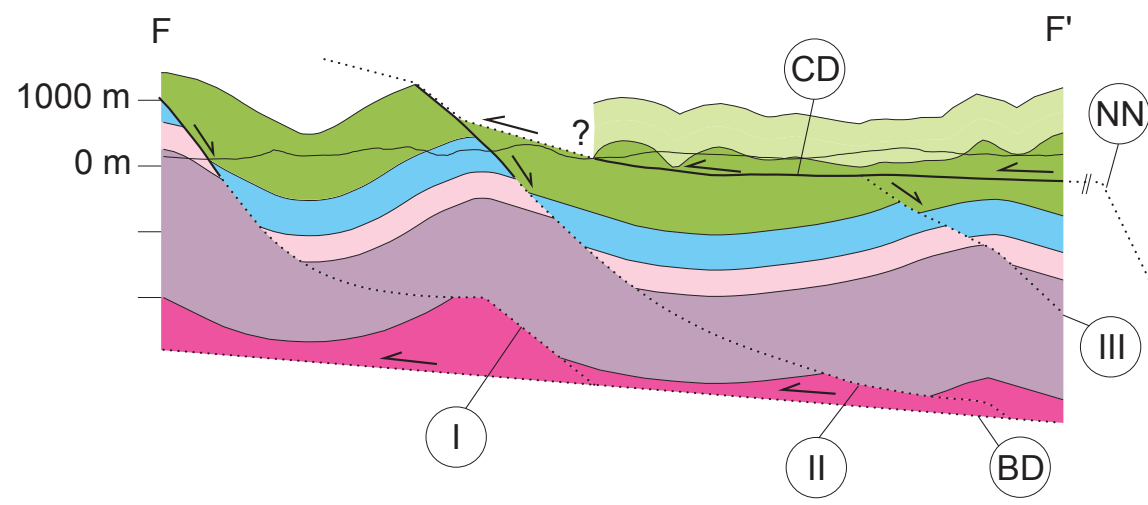

D

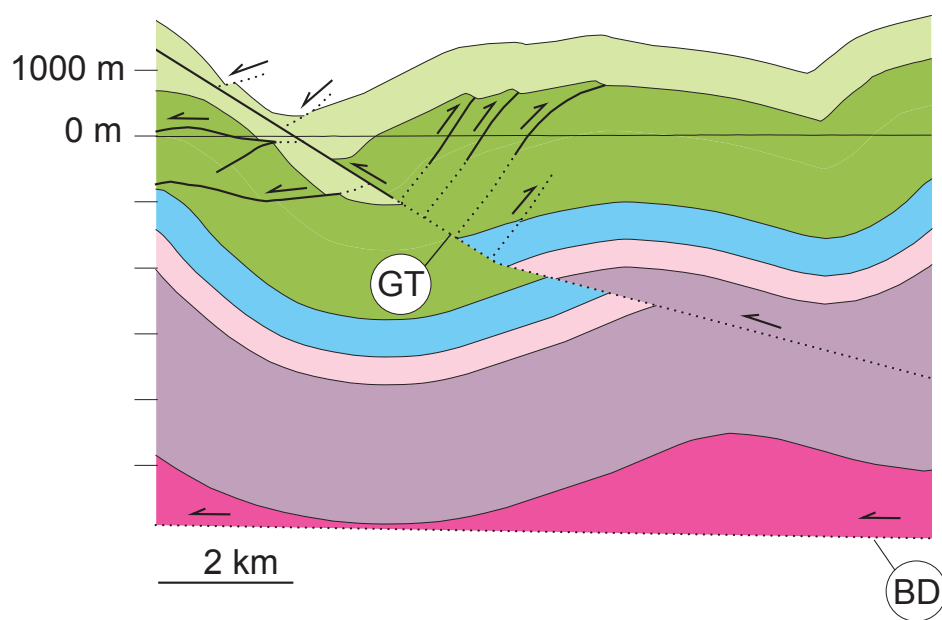

$\mathrm{N}$

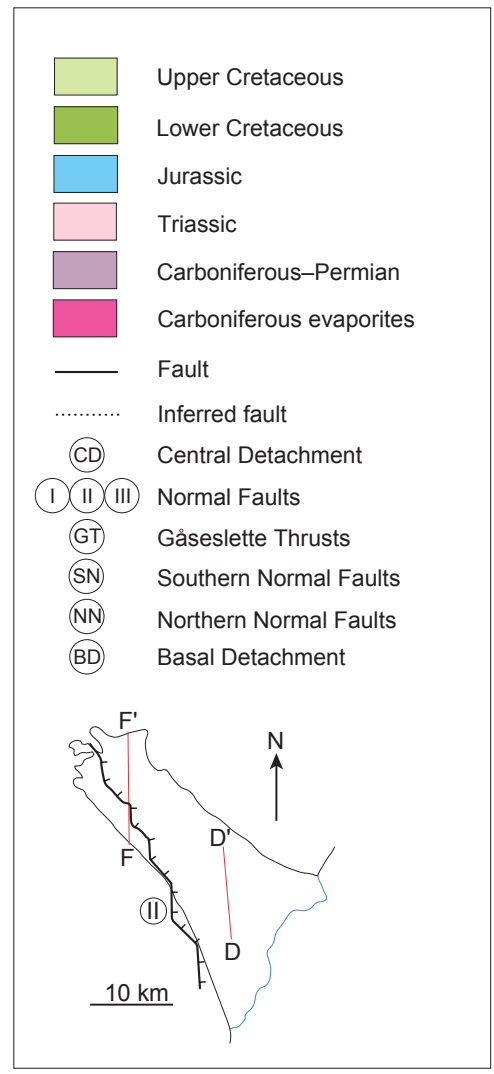

Figure 4. Generalised balanced cross-sections from Kilen modified from Svennevig et al. (2016a). The cross-sections are also shown in the 3D model in the Electronic Supplement.

restoration was carried out in the software Move 2014.2 from Midland Valley using the workflow described in Svennevig et al. (2015) and the detailed 3D model and geological interpretation of Svennevig et al. (2016a). To simplify the 3D model, restoration focuses on the main faults (Fig. 2; Table 1) and a regionally recognisable 
Table 1. Overview of inferred (I) and observed (O) faults on Kilen based mainly on Svennevig et al. (2016a, b). The faults are also showed in Figs. 2 and 4.

\begin{tabular}{|c|c|c|c|c|c|c|c|}
\hline Name & Type & $\begin{array}{l}\text { Abbrevi- } \\
\text { ation }\end{array}$ & Description & $\begin{array}{l}\text { Structural } \\
\text { Phase }\end{array}$ & $\begin{array}{l}\text { Inferred/ } \\
\text { Observed }\end{array}$ & $\begin{array}{l}\text { Minimum } \\
\text { offset }\end{array}$ & Reference \\
\hline Fault I & Normal & I & $\begin{array}{l}\text { Westernmost folded normal fault exposed in } \\
\text { the Kuglelejet anticline. }\end{array}$ & D1 & $\mathrm{O}$ & $1200 \mathrm{~m}$ & $\begin{array}{l}\text { (Svennevig et al., } \\
\text { 2016a) }\end{array}$ \\
\hline Fault II & Normal & II & $\begin{array}{l}\text { Central folded normal fault. Zig-zag fault } \\
\text { trace exposed throughout Kilen Fjelde. }\end{array}$ & D1 & $\mathrm{O}$ & $780 \mathrm{~m}$ & $\begin{array}{l}\text { (Svennevig et al., } \\
\text { 2016a) }\end{array}$ \\
\hline Fault III & Normal & III & $\begin{array}{l}\text { Eastern folded normal fault. Poorly exposed, } \\
\text { mainly inferred from stratigraphic separation. }\end{array}$ & D1 & I & $?$ & $\begin{array}{l}\text { (Svennevig et al., } \\
\text { 2016a) }\end{array}$ \\
\hline $\begin{array}{l}\text { Southern } \\
\text { Normal Faults }\end{array}$ & Normal & SN & $\begin{array}{l}\text { Series of minor faults interpreted to be } \\
\text { antithetic normal faults to an unexposed } \\
\text { larger normal to the W (LS). }\end{array}$ & D1 & $\mathrm{O}$ & $\begin{array}{l}\text { Several } 100 \\
\mathrm{~m}\end{array}$ & $\begin{array}{l}\text { (Svennevig et al., } \\
\text { 2016b) }\end{array}$ \\
\hline $\begin{array}{l}\text { Northern } \\
\text { Normal fault }\end{array}$ & Normal & $\mathrm{NN}$ & $\begin{array}{l}\text { Normal fault inferred to be present to the } \\
\text { NE of Kilen from the younger on older } \\
\text { stratigraphic relationship across the CD. }\end{array}$ & D1 & I & $500 \mathrm{~m}$ & $\begin{array}{l}\text { This paper, } \\
\text { (Svennevig et al., } \\
\text { 2016a) }\end{array}$ \\
\hline $\begin{array}{l}\text { Large southern } \\
\text { normal fault }\end{array}$ & Normal & LS & $\begin{array}{l}\text { The SE extrapolation of Fault I inferred by } \\
\text { the presence of the reverse listric fan com- } \\
\text { prising the SN. }\end{array}$ & D1 & I & $?$ & $\begin{array}{l}\text { This paper, } \\
\text { (Svennevig et al., } \\
\text { 2016a) }\end{array}$ \\
\hline $\begin{array}{l}\text { Central } \\
\text { Detachment }\end{array}$ & $\begin{array}{l}\text { Reverse, } \\
\text { sub-horizontal }\end{array}$ & $\mathrm{CD}$ & $\begin{array}{l}\text { Detachment in Kilen Fjelde separating Upper } \\
\text { Cretaceous strata of the Hondal Elv Thrust } \\
\text { Sheet from Triassic - lowermost Upper } \\
\text { Cretaceous strata of the Kilen Thrust Sheet. }\end{array}$ & D2 & $\mathrm{O}$ & $1500 \mathrm{~m}$ & $\begin{array}{l}\text { This paper, } \\
\text { (Svennevig et al., } \\
\text { 2016a) }\end{array}$ \\
\hline $\begin{array}{l}\text { Basal } \\
\text { Detachment }\end{array}$ & $\begin{array}{l}\text { Reverse, } \\
\text { sub-horzontal }\end{array}$ & $\mathrm{BD}$ & $\begin{array}{l}\text { Basal detachment inferred from the } \\
\text { geometry of the folds and the thickness of } \\
\text { the known sediments. }\end{array}$ & D2 & I & $?$ & $\begin{array}{l}\text { This paper, } \\
\text { (Svennevig et al., } \\
\text { 2016a) }\end{array}$ \\
\hline $\begin{array}{l}\text { Gåseslette } \\
\text { Thrusts }\end{array}$ & Reverse, steep & GT & $\begin{array}{l}\text { Large south-verging frontal thrusts and } \\
\text { three back thrusts visible in aerial photos on } \\
\text { Gåseslette. }\end{array}$ & D2 & $\mathrm{O}$ & $\begin{array}{l}\text { Main thrust } \\
1250 \mathrm{~m} \text {, } \\
\text { Backthrusts } \\
740 \mathrm{~m}\end{array}$ & $\begin{array}{l}\text { (Svennevig et al., } \\
\text { 2016a) }\end{array}$ \\
\hline
\end{tabular}

mid-Cretaceous horizon corresponding to the top of the Hondal and Galadriel Fjeld unit in Kilen Fjelde and the top of the Kangoq Ryg unit at Gåseslette (Figs. 2 \& 4; Electronic Supplement; cf., Svennevig et al., 2016a).

\section{Restoring the 3D model}

The restoration of the basin consists of three steps: 1) restoring major thrusts (D2);2) unfolding the midCretaceous horizon and the D2-folded D1 faults; and 3) extrapolating the unfolded horizon and faults to form a coherent 3D model.

\section{Step 1: Restoring major reverse faults}

The major reverse faults associated with D2 (Fig. 2; Table 1) have been restored assuming a generalised basal detachment below the Kilen Thrust Sheet (BD, Table 1; cf., Svennevig et al., 2016a). In the southern part of the Kilen Thrust Sheet at Gåseslette, the D2 faulting is mainly accommodated by the frontal Gasseslette Thrust (GT, Table 1). This thrust has been merged with the constructed basal detachment (BD), and the strata above the fault have been restored by aligning the midCretaceous horizon on either side of the thrust. To the north, in Kilen Fjelde, D2 faulting is represented by the Central Detachment (CD, Table 1). It is interpreted to link up with an unexposed, D2-inverted, D1 normal fault to the northeast below the ice sheet: the Northern Normal Fault (NN, Table 1). The fault trace of the Northern Normal Fault has been constructed at a minimum distance from Kilen as a linear fault trace following the general NNW-SSE orientation of basinforming faults in the Wandel Sea Basin (Håkansson \& Stemmerik, 1989; Zink-Jørgensen, 1994; Stemmerik et al., 2000) and parallel to normal faults at Kilen (Svennevig et al., 2016a). The 3D fault plane is constructed with a dip of $44^{\circ}$ similar to the pre-folding dip of normal Fault I. The Central Detachment has been extended to the north using a generalised strike of $175^{\circ}$ and dip of $6^{\circ}$ to the east and linked to the Northern Normal Fault. Assuming tectonic transport from north to south (Lyberis \& Manby, 1999; Manby \& Lyberis, 2000; Gosen \& Piepjohn, 2003; Guarnieri, 2015; Svennevig et al., 2016a), the strata of the Hondal Elv Thrust Sheet have been restored along the Central Detachment towards the north and down the inverted northern normal fault. This results in a minimum tectonic transport of the Hondal Elv Thrust Sheet along the Central Detachment of $15 \mathrm{~km}$.

To constrain the vertical movement of the Hondal Elv Thrust Sheet along the inverted Northern Normal Fault, the thermal history of Kilen Fjelde has been addressed based on data in Håkansson et al. (1994b) and Pedersen \& Håkansson (1999). Additional thermal data can be found in Stemmerik et al. (1997). From the locality 
Table 2. Vitrinite data (Rmax) from Håkansson et al. (1994b) with locality and sample descriptions from the GEUS sample database translated from Danish. The data are plotted in Fig. 5. Thrust sheets are from (Svennevig et al., 2016a).

\begin{tabular}{|c|c|c|c|c|c|c|}
\hline & GEUS Number & Age & $R \max$ & Rmax deviation & Description & Locality \\
\hline \multirow{4}{*}{ 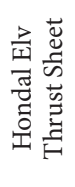 } & 216153 & Late Cretaceous & 2.45 & 0.08 & Shale & Kilen profile $\mathrm{N}$ of camp 10. \\
\hline & 216171 & Late Cretaceous & 2.14 & 0.1 & Sandstone, fine, chipped & Kilen, profile NE of camp 10. \\
\hline & 216182 & Late Cretaceous & 2.32 & 0.11 & Shale & Kilen, profile V of camp 10. \\
\hline & 220328 & Late Cretaceous & 2.08 & 0.1 & Shale, black & South-East of $2 \mathrm{~A}$ \\
\hline \multirow{5}{*}{ 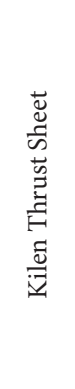 } & 216101 & $\begin{array}{l}\text { Late Jurassic - } \\
\text { Early Cretaceous }\end{array}$ & 2.2 & 0.08 & Shale & $\begin{array}{l}\text { Kilen, profile WNW } \\
+ \text { camp } 5\end{array}$ \\
\hline & 216120 & $\begin{array}{l}\text { Late Jurassic - } \\
\text { Early Cretaceous }\end{array}$ & 2.06 & 0.12 & Shale & Kilen, profile NW of camp 5 ? \\
\hline & 216144 & $\begin{array}{l}\text { Late Jurassic - } \\
\text { Early Cretaceous }\end{array}$ & 1.99 & 0.1 & Shale, unit h & Kilen Profile SE of camp 5. \\
\hline & 216135 & $\begin{array}{l}\text { Late Jurassic - } \\
\text { Early Cretaceous }\end{array}$ & 1.53 & 0.06 & $\begin{array}{l}\text { Shale, silty, loose, } \\
\text { collected in scree }\end{array}$ & Kilen S of Camp 5. x4 179223 \\
\hline & 216127 & $\begin{array}{c}\text { Late Jurassic- } \\
\text { Early Cretaceous }\end{array}$ & 2.07 & 0.1 & Shale, silty & Kilen S of Camp 5. x4 179223 \\
\hline
\end{tabular}

descriptions in the sample database (Table 2) it is possible to place the samples in an $\mathrm{N}-\mathrm{S}$ transect roughly along the F-F' section trace (Fig. 2). A step in the thermal maturity across the Central Detachment is not directly observable (Fig. 5) but the strata now recognised to be the Hondal Elv Thrust Sheet generally have higher Rmax values averaging 2.25 compared to 2.08 in the Kilen Thrust Sheet (Table 2; Håkansson et al., 1994b). Mathiesen et al. (1997) produced a Rmax/depth chart for eastern Amdrup Land, $40 \mathrm{~km}$ southwest of Kilen, with a gradient of $0.53 \mathrm{Rmax} / \mathrm{km}$. Applying this gradient to the lower Upper Cretaceous samples of the Hondal Elv Thrust Sheet gives a burial depth of $3.3 \mathrm{~km}$ while the uppermost Lower Cretaceous samples of the Kilen Thrust Sheet in northern Kilen were covered by $2.8 \mathrm{~km}$ of sediments.
These are estimated depths as the bed thicknesses at the sample sites are poorly constrained. The difference of $500 \mathrm{~m}$ is believed to represent the down-throw along the Northern Normal Fault.

Step 2: Unfolding the folded faults and mid-Cretaceous horizon

For each of the fault blocks a datum plane was constructed through the core of the deepest syncline in the mid-Cretaceous horizon. Each of the fault blocks was then unfolded to this surface. Normal faults I, II and III are unfolded along with the strata of fault block 1. On Gåseslette, the datum is tilted by $10^{\circ} \mathrm{W}$ to account for the $10^{\circ}$ westward plunge of fold axes in this area (Svennevig et al., 2015, 2016a).

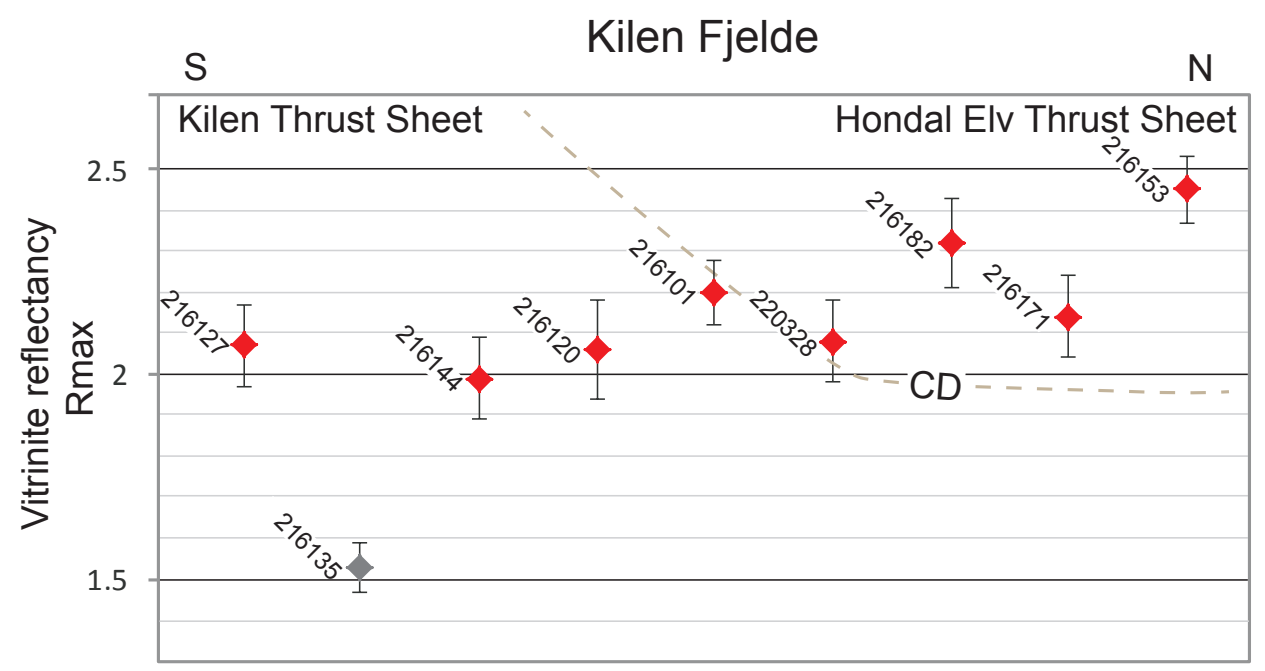

Figure 5. Vitrinite data (Rmax) for Kilen Fjelde adapted from Håkansson et al. (1994b) showing the thermal maturity of sediments. Although the samples are not given with geographical coordinates, from the locality descriptions in the GEUS sample database (Table 2) it was possible to place them on a relative $N-S$ transect through Kilen Fjelde roughly along the F-F' section trace (Fig. 2). The Hondal Elv and the Kilen Thrust Sheets along with the Central Detachment (CD) are shown on the diagram relative to the samples. Sample 216135 is disregarded as it is a loose hand sample collected in a scree according to the sample description (Table 2). 

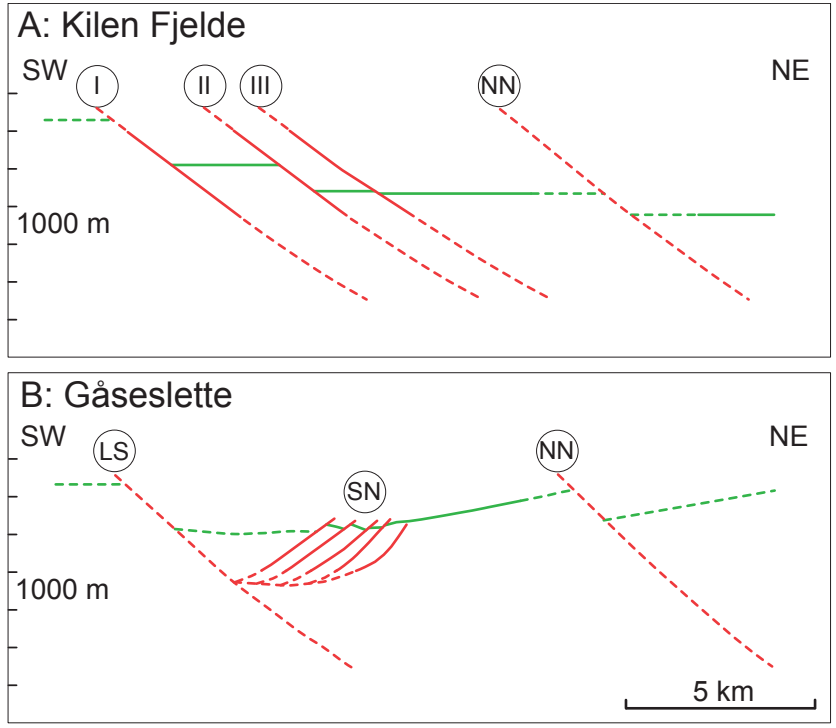

Figure 6. Cross-sections through the restored 3D model in (A) Kilen Fjelde and (B) Gåseslette. Stippled lines are inferred whereas full lines are observed. The cross-sections are also shown in the restored $3 D$ model in the Electronic Supplement. Abbreviations as in Table 1.

Step 3: Extrapolating the horizon and the faults To form a coherent 3D model, the restored patches of the mid-Cretaceous horizon and the faults have been extrapolated linearly along the basin trends beyond their relatively small extent. Fault I is extended along strike towards the southeast and linked up with the large southern normal fault (LS, Table 1).

\section{Geometry of the restored geology}

The restored pre-folding geology of Kilen is characterised by fault blocks separated by NNW-SSE-striking and ENE-dipping faults (Fig. 6; Electronic Supplement). The northeastern part consists of five, $1.5-8 \mathrm{~km}$-wide, fault blocks separated by three well constrained normal faults; Faults I, II and III and the inferred Northern Normal fault. Fault I has the largest offset of minimum $1200 \mathrm{~m}$, Fault II has a minimum offset of $780 \mathrm{~m}$, while the offset on Fault III is unknown (Svennevig et al., 2016a). The offset of the Northern Normal Fault is estimated to 500 $\mathrm{m}$ based on vitrinite data (Fig. 6A). In the southeastern part of the area a single larger fault block is deformed by a series of relatively small antithetic faults interpreted to be a reverse listric fan (cf., Gibbs, 1984) to the unexposed southern continuation of Fault I or II (LS, Fig. 6B, Table 1; Svennevig et al., 2016a). The southeastern continuation of the Northern Normal fault is assumed to be the northeast termination of the fault block (Fig. 6B). The fault block thus has a minimum width of $10 \mathrm{~km}$. A $10^{\circ}$ westward plunge of fold axes on Gåseslette is here interpreted to reflect a $10^{\circ} \mathrm{W}$ pre-folding dip of the strata in this area and could be due to a large-scale rollover anticline or rotation of the larger southern fault block during extension.

\section{Discussion}

The Kilen Cretaceous basin has been restored using 3D modelling of data obtained from integrated oblique photogrammetry and field data (Svennevig et al., 2015, 2016a). A series of NNW-SSE-striking normal faults has been visualised. This geometry resembles a rift basin architecture (e.g., Gibbs, 1984; Bosworth, 1985; Peacock et al., 2000) and structures observed in analogue models of rift basins (McClay et al., 2002). Based on this, we suggest that the restored faults and fault blocks at Kilen are part of a Cretaceous rift basin (Fig. 7) that has been obscured by later inversion and extensive ice and sea cover (Fig. 1). The more than $600 \mathrm{~m}$-thick, Upper Cretaceous Nakkehoved Formation (Nielsen, 1941; Dawes, 1976; Håkansson, 1979) northeast of Kilen may be a more distal part of the basin, although very little is known of this area and the age is poorly constrained.

This interpretation is in contrast to previous views on the Mesozoic evolution of Kilen involving strike-slip movement and being composed of five, isolated pullapart basins separated by inferred strike-slip faults as part of the "Wandel Hav Strike Slip Mobile Belt" ( Håkansson \& Pedersen, 1982, 2015; Pedersen \& Håkansson, 1999).

\section{Timing of normal faulting}

The D1 normal faults predate D2 compression of presumed Palaeocene-Eocene age (Svennevig et al., 2016a), and since Coniacian sediments of the Hondal Elv Thrust Sheet were down-faulted (D1) before they were inverted along the Central Detachment (D2), movements along fault I-III can be dated to post-Coniacian times suggesting that Coniacian sediments are pre- or synrift. The Cretaceous succession at Kilen is more than $2 \mathrm{~km}$ thick of which up to $1500 \mathrm{~m}$ are of Aptian-Albian age. Aptian-Albian and older activity on the faults can be inferred based on the thickness variation of units of this age across fault II (Pedersen, 1989; Svennevig et al., 2016a) indicating multiphase rifting. Faults with similar orientation are described from other localities in the Wandel Sea Basin as having been active during Late Palaeozoic and Early Mesozoic times (Fig. 1; ZinkJørgensen, 1994; Stemmerik et al., 1996, 2000), and it is likely that the normal faults on Kilen were also active in pre-Cretaceous times. Thórarinsson et al. (2015) dated NW-SE-striking dykes in Peary Land to $c .85 \mathrm{Ma}$ (Santonian) indicating NE-SW extension at that time. These dykes are parallel to faults of the Trolle Land Fault System (Fig. 1) and their age falls within the possible agespan of post-Coniacian movement on the normal faults observed on Kilen. 


\section{Implications for the Wandel Sea Basin}

The reconstruction of the strata at Kilen is only a small window into the Wandel Sea Basin. Our work on Kilen allows for an alternative interpretation for the NNWSSE-oriented faults affecting Mesozoic sediments elsewhere in the Wandel Sea Basin (Fig. 1). NNW-SSEstriking horsts and grabens are known from the Upper Palaeozoic of Amdrup Land (Stemmerik et al., 2000) and faults with a similar strike and fault spacing occur in the Trolle Land Fault System in eastern Peary Land (Bengaard \& Henriksen, 1984; Zink-Jørgensen, 1994; Zink-Jørgensen \& Håkansson, 1994; Stemmerik et al., 1996).

\section{Comparison to the conjugate margin and surrounding basins}

Deep Cretaceous basins and Late Cretaceous-Palaeocene normal faulting are also known from the southwest Barents Sea margin (Gabrielsen et al., 1990; Faleide et al., 1993, 2008, 2010; Clark et al., 2013; Gernigon et al., 2014; Safronova et al., 2015). Breivik et al. (1998) reported significant Late Cretaceous-Early Palaeogene normal faulting along the southwestern margin of the Barents Sea with offsets of up to $1 \mathrm{~km}$ on individual faults and a cumulative offset of $9 \mathrm{~km}$ based on recognition of a 'mid' Cretaceous reflector. The thick Cretaceous sedimentary package and the possible Aptian-Albian and postConiacian activity on the Kilen faults resemble the pattern observed on the conjugate southwest Barents Sea margin in the Harstad, Tromsø, Bjørnøya, Sørvestnaget and Hammerfest basins (Gabrielsen et al., 1990). In particular, the northern part of the Bjørnøya Basin (Gabrielsen et al., 1990; Clark et al., 2013; Gernigon et al., 2014) has a strong resemblance to the basin at Kilen and the two areas were only $100-200 \mathrm{~km}$ apart in preopening times (Fig. 7; Müller et al., 2016).

In contrast, Cretaceous basins are not observed on the northwest Barents Sea margin north of Bjørnøya and offshore Svalbard (Faleide et al., 2008; Anell et al., 2014), and large-scale Mesozoic normal faulting is not recorded on Svalbard. Large, Late Palaeozoic lineaments of the Billefjorden and Lomfjorden fault complexes were not reactivated during the Late Mesozoic (Haremo et al., 1990; Dypvik et al., 1991; McCann \& Dallmann, 1996).

The northern part of the offshore Danmarkshavn Basin $50 \mathrm{~km}$ to the south of Kilen (Fig. 7) is poorly constrained due to a lack of seismic data and thus its relationship to the Wandel Sea Basin is uncertain. Thick Cretaceous packages controlled by NNE-SSE-striking structures are described from the southern and central parts of the basin (Hamann et al., 2005).

The outlined Mesozoic history of Kilen seems to be more similar to the southwest Barents Sea margin south of

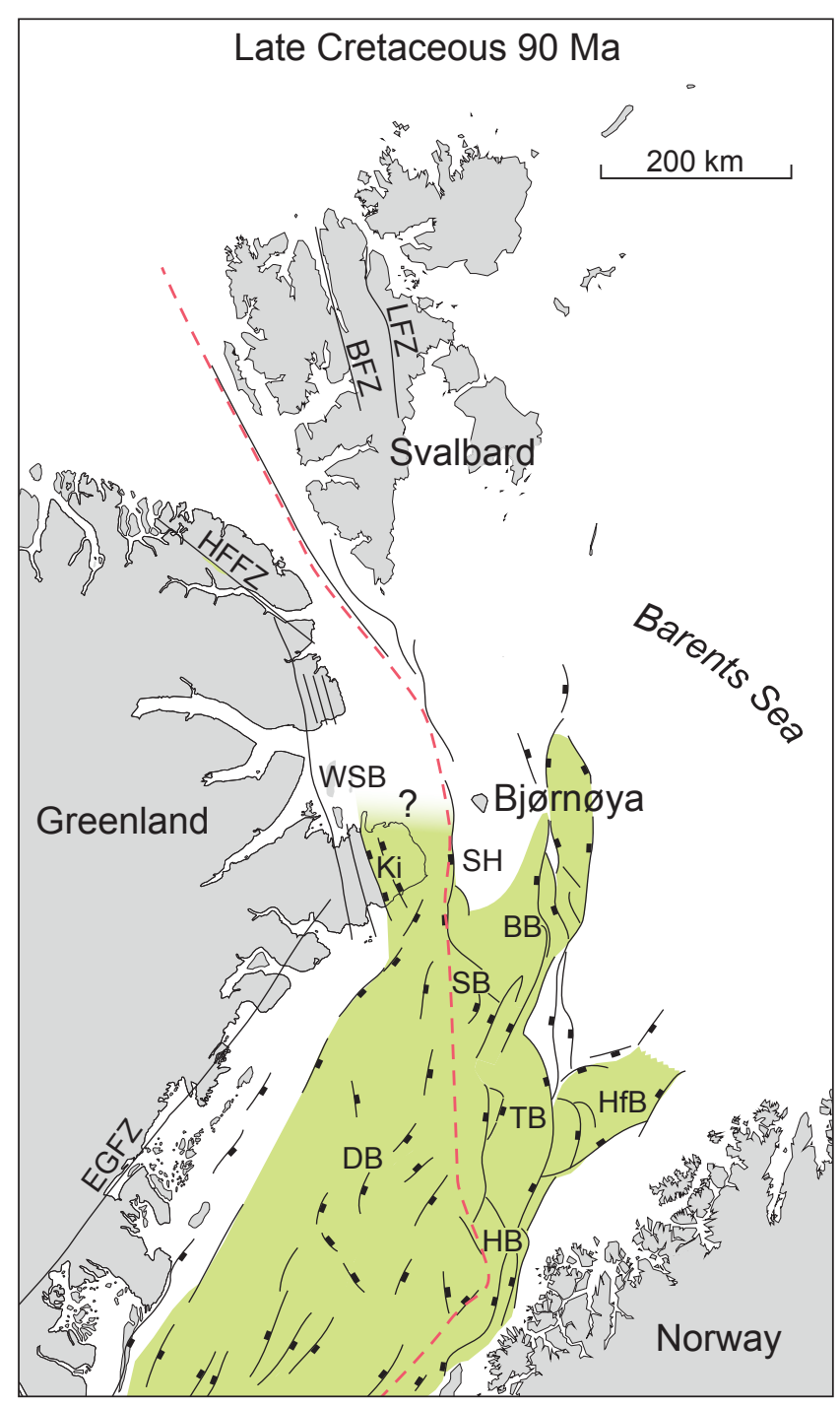

Figure 7. Late Cretaceous (90 Ma) plate reconstruction (Müller et al., 2016) produced in Gplates 1.5 (Boyden et al., 2011) showing present-day coastlines along with Cretaceous rift basins (green) and faults simplified from Faleide et al. (2015) and this study. Note the pre-opening proximity of Kilen (Ki) to the southwest Barents shelf and the Bjørnøya Basin (BB). The red stippled line marks the approximate zone of later oceanic opening. The Palaeocene-Eocene compression on either margin is not restored. Abbreviations: WSB - Wandel Sea Basin, Ki - Kilen, HFFZ - Harder Fjord Fault Zone, EGFZ - East Greenland Fault Zone, DB - Danmarkhavn Basin, BFZ - Billefjorden Fault Zone, LFZ - Lomfjorden Fault Zone, SH - Stappen High, BB - Bjørnøya Basin, TB - Tromsø Basin, HfB Hammerfest Basin, SB - Sørvestnaget Basin, HB - Harstad Basin.

Bjørnøya than to Svalbard. This is in agreement with Late Cretaceous global plate reconstructions (Müller et al., 2016) where Kilen is close to the southwest Barents Sea (Fig. 7). In contrast, thin-skinned folding and thrusting is reported from both Svalbard (e.g., Braathen \& Bergh, 1995) and Kilen (Svennevig et al., 2016a) but only relatively minor inversion is observed on the southwest Barents Sea margin (Gabrielsen et al., 1997), in line with global plate reconstructions (Müller et al., 2016) where Kilen in Palaeocene-Eocene times was close to Svalbard. 
Viewed in a plate reconstruction context, the Cretaceous basin at Kilen can be interpreted as a basin that developed between Greenland to the west and the Stappen High to the east, today on the conjugate Barents Sea margin (Fig. 7). The Late Cretaceous of Kilen might thus be the western side of a successful rift that eventually resulted in the opening of the North Atlantic and in that framework Kilen is an eastern North Greenland equivalent to the Bjørnøya Basin.

\section{Conclusions}

We present a restoration of a 3D structural model of Kilen revealing a Cretaceous rift basin highlighted by a mid-Cretaceous horizon offset by several down-to-theENE normal faults. The restoration is based on mapping from oblique photogrammetry, ground observations and previously published data.

The interpretation of a Cretaceous rift basin at Kilen points to an alternative explanation for NNW-SSEoriented faults affecting Mesozoic sedimentary rocks elsewhere in the Wandel Sea Basin, suggesting rather that they are normal faults formed during extension.

The Cretaceous history of the eastern North Greenland margin as exposed on Kilen is more similar to the southwest Barents Sea margin south of Bjørnøya than to Svalbard and in particular to the Bjørnøya Basin, which is in accordance with Late Cretaceous plate reconstructions. The two basins were separated by the Stappen High and the basin at Kilen could thus be the western part of a successful rift that eventually was split in two by the later opening of the North Atlantic.

Acknowledgements. Winfried Dallmann and an anonymous reviewer are thanked for constructive reviews. Thanks are due to Geocenter Denmark, The Natural History Museum of Denmark and GEUS for funding the $\mathrm{PhD}$ project of which this work is a part. GEUS is thanked for providing and financing the logistic platform for the field based part of the work. Jette Halskov (GEUS) is thanked for assistance drafting the figures. Christian Brogaard Pedersen (GEUS) is thanked for assistance compiling the 3D pdf files in the Electronic Supplement. Midland Valley Exploration Ltd. is thanked for the use of Move software under the Academic Software Initiative (ASI). The paper is published with the permission of GEUS.

\section{References}

Alsen, P., McRoberts, C., Svennevig, K., Bojesen-Koefoed, J.A., Hovikoski, J. \& Piasecki, S. 2017: The Isrand Formation: a Middle Triassic Daonella-bearing, black shale unit in Kilen, North Greenland (with a note on the Triassic in Amdrup Land). Newsletters on Stratigraphy 50,31-46. https://doi.org/10.1127/nos/2016/0341.

Anell, I., Braathen, A. \& Olaussen, S. 2014: Regional constraints of the Sørkapp Basin: A Carboniferous relic or a Cretaceous depression? Marine and Petroleum Geology 54, 123-138. https://doi.org/10.1016/j.marpetgeo.2014.02.023.

Bengaard, H.-J. \& Henriksen, N. 1984: Geological map of Greenland, Sheet 8, Peary Land, scale 1:500,000, Geological Survey of Greenland.

Bojesen-Koefoed, J.A., Alsen, P. \& Christiansen, F.G. 2014: Six years of petroleum geological activities in North-East Greenland (2008 - 2013): projects and a view of the future. Geoligical Survey of Denmark and Greenland Bulletin 31,59-62.

Bosworth, W. 1985: Geometry of propagating continental rifts. Nature 316, 625-627. https://doi.org/10.1038/316625a0.

Boyden, J.A., Müller, R.D., Gurnis, M., Ivey-law, H., Watson, R.J. \& Cannon, J.S. 2011: Next-generation plate-tectonic reconsttuctions using GPlates. In Keller, G.R. \& Baru, C. (eds.): Geoinformatics: Cyberinfrastructure for the Solid Earth Sciences, Cambridge University Press, Cambridge, pp. 95-113 https://doi.org/10.1017/CBO9780511976308.008.

Braathen, A. \& Bergh, S.G. 1995: Kinematics of Tertiary deformation in the basement-involved fold-thrust complex, western Nordenskiøld Land, Svalbard: Tectonic implications based on fault-slip data. Tectonophysics 249, 1-29. https://doi.org/10.1016/0040-1951(95)00036-M.

Breivik, A.J., Faleide, J.I. \& Gudlaugsson, S.T. 1998: Southwestern Barents Sea margin: late Mesozoic sedimentary basins and crustal extension. Tectonophysics 293, 21-44. https://doi.org/10.1016/S0040-1951(98)00073-0.

Clark, S.A., Glorstad-Clark, E., Faleide, J.I., Schmid, D., Hartz, E.H. \& Fjeldskaar, W. 2013: Southwest Barents Sea rift basin evolution: comparing results from backstripping and time-forward modelling. Basin Research 25, 1-17.

Dawes, P.R. 1976: Precambrian to Tertiary of northern Greenland. In Escher, A. \& Watt, W.S. (eds.): Geology of Greenland, Grønlands Geologiske Undersøgelser, Copenhagen, pp. 248-303.

Dawes, P.R. \& Soper, N.J. 1973: Pre-Quaternary History of North Greenland: Regional Arctic Geology of the Nordic Countries. American Association of Petroleum Geologists Memoir 19, 117-134.

Dypvik, H., Nagy, J., Eikeland, T.A., Backer-Owe, K. \& Johansen, H. 1991: Depositional conditions of the Bathonian to Hauterivian Janusfjellet Subgroup, Spitsbergen. Sedimentary Geology 72, 55-78. https://doi.org/10.1016/0037-0738(91)90123-U.

Dypvik, H., Håkansson, E. \& Heinberg, C. 2002: Jurassic and Cretaceous palaeogeography and stratigraphic comparisons in the North Greenland-Svalbard region. Polar Research 21, 91-108. https://doi.org/10.1111/j.1751-8369.2002.tb00069.x.

Faleide, J.I., Vågnes, E. \& Gudlaugsson, S.T. 1993: Late MesozoicCenozoic evolution of the south-western Barents Sea in a regional rift-shear tectonic setting. Marine and Petroleum Geology 10, 186214. https://doi.org/10.1016/0264-8172(93)90104-Z.

Faleide, J.I., Tsikalas, F., Breivik, A.J., Mjelde, R., Ritzmann, O., Engen, Ø., Wilson, J. \& Eldholm, O. 2008: Structure and evolution of the continental margin off Norway and the Barents Sea. Episodes 31, 82-91.

Faleide, J.I., Bjørlykke, K. \& Gabrielsen, R.H. 2010: Geology of the Norwegian Continental Shelf. In Bjørlykke, K. (ed.): Petroleum Geoscience: From Sedimentary Environments to Rock Physics, Springer Berlin Heidelberg, Berlin, Heidelberg, pp. 467-499. https://doi.org/10.1007/978-3-642-02332-3_22. 
Faleide, J.I., Bjørlykke, K. \& Gabrielsen, R.H. 2015: Geology of the Norwegian Continental Shelf. In Bjørlykke, K. (ed.): Petroleum Geoscience, Springer Berlin Heidelberg, Berlin, pp. 603-637. https://doi.org/10.1007/978-3-642-34132-8_25.

Gabrielsen, R.H., Færseth, R.B., Jensen, L.N., Kalheim, J.E. \& Riis, F. 1990: Structural elements of the Norwegian continental shelf Part I: The Barents Sea Region. Norwegian Petroleum Directorate Bulletin 6, 1-33.

Gabrielsen, R.H., Grunnaleite, I. \& Rasmussen, E. 1997: Cretaceous and tertiary inversion in the Bjørnøyrenna Fault Complex, southwestern Barents Sea. Marine and Petroleum Geology 14, 165-178. https://doi.org/10.1016/S0264-8172(96)00064-5.

Gernigon, L., Brönner, M., Roberts, D., Olesen, O., Nasuti, A. \& Yamasaki, T. 2014: Crustal and basin evolution of the southwestern Barents Sea: From Caledonian orogeny to continental breakup. Tectonics 33, 347-373. https://doi.org/10.1002/2013TC003439.

Gibbs, A.D. 1984: Structural evolution of extensional basin margins. Journal of the Geological Society of London 141, 609-620. https://doi.org/10.1144/gsjgs.141.4.0609.

Gosen, W. von \& Piepjohn, K. 2003: Eurekan transpressive deformation in the Wandel Hav Mobile Belt (northeast Greenland). Tectonics 22, 1-28. https://doi.org/10.1029/2001TC901040.

Guarnieri, P. 2015: Pre-break-up palaeostress state along the East Greenland margin. Journal of the Geological Society of London 172, 727-739. https://doi.org/10.1144/jgs2015-053.

Hamann, N.E., Whittaker, R.C. \& Stemmerik, L. 2005: Geological development of the Northeast Greenland Shelf. In Doré, A.G. \& Vining, B.A. (eds.): Petroleum Geology: North-West Europe and Global Perspectives-Proceedings of the 6th Petroleum Geology Conference, Geological Society of London, pp. 887-902. https://doi.org/10.1144/0060887.

Haremo, P., Andresen, A., Dypvik, H., Nagy, J., Elverhøi, A., Eikeland, T.A. \& Johansen, H. 1990: Structural development along the Billefjorden Fault zone in the area between Kjellstromdalen and Adventdalen/Sassendalen, central Spitsbergen. Polar Research 8, 195-216. https://doi.org/10.3402/polar.v8i2.6812.

Håkansson, E. 1979: Carboniferous to Tertiary development of the Wandel Sea Basin, eastern North Greenland. Rapport Grønlands Geologiske Undersøgelse 83, 73-83.

Håkansson, E. 1988: Did Tertiary compressional tectonics affect north Greenland? Summary of the evidence. Norsk Polarinstitut Rapport $46,101-104$.

Håkansson, E. \& Pedersen, S.A.S. 1982: Late Paleozoic to Tertiary tectonic evolution of the continental margin in North Greenland. Arctic Geology and Geophysics: Proceedings of the Third International Symposium on Arctic Geology - Memoir 8, 331-348.

Håkansson, E. \& Pedersen, S.A.S. 2001: The Wandel Hav Strike-Slip Mobile Belt - A Mesozoic plate boundary in North Greenland. Bulletin of the Geological Society of Denmark 48, 149-158.

Håkansson, E. \& Pedersen, S.A.S. 2015: A healed strike-slip plate boundary in North Greenland indicated through associated pullapart basins. Geological Society of London Special Publications 413, 143-169. https://doi.org/10.1144/SP413.10.

Håkansson, E. \& Stemmerik, L. 1989: Wandel Sea basin - A new synthesis of the late Paleozoic to Tertiary accumulation in North Greenland. Geology 17, 683-686. https://doi.org/10.1130/0091-7613(1989)017<0683:WSBANS>2.3.CO;2.

Håkansson, E., Heinberg, C. \& Stemmerik, L. 1981: The Wandel Sea Basin from Holm Land to Lockwood $\varnothing$, eastern North Greenland. Rapport Grønlands Geologiske Undersøgelse 106, 46-63.

Håkansson, E., Heinberg, C. \& Stemmerik, L. 1991: Mesozoic and Cenozoic history of the Wandel Sea Basin area, North Greenland. Bulletin Grønlands Geologiske Undersøgelse 160, 153-164.

Håkansson, E., Birkelund, T., Heinberg, C., Hjort, C., Mølgaard, P. \& Pedersen, S.A.S. 1993: The Kilen Expedition 1985. Bulletin of the Geological Society of Denmark 40, 9-32.
Håkansson, E., Pedersen, S.A.S. \& Heinberg, C. 1994a: Geology of Kilen. In Håkansson, E. (ed.): Wandel Sea Basin: Basin Analysis, University of Copenhagen, Copenhagen.

Håkansson, E., Piasecki, S., Konnerup-Madsen, J. \& Thomsen, E. 1994b: A late, thermal event in the Wandel Sea Basin; eastern North Greenland. In Håkansson, E. (ed.): Wandel Sea Basin: Basin Analysis, University of Copenhagen, Copenhagen.

Leever, K.A., Gabrielsen, R.H., Faleide, J.I. \& Braathen, A. 2011: A transpressional origin for the West Spitsbergen fold-andthrust belt: Insight from analog modeling. Tectonics 30, 1-24. https://doi.org/10.1029/2010TC002753.

Lyberis, N. \& Manby, G. 1999: The Eurekan Deformation of North and Eastern North Greenland. Polarforschung 69, 95-106.

Manby, G. \& Lyberis, N. 2000: Pre-ocean opening compression of the Northwestern Atlantic margin: evidence from eastern North Greenland. Journal of the Geological Society of London 157, 707710. https://doi.org/10.1144/jgs.157.4.707.

Mathiesen, A., Dalhoff, F. \& Stemmerik, L. 1997: Oil geology and thermal history of eastem North Greenland. Geological Survey of Denmark and Greenland Report 1997-49, 21-139.

McCann, A.J. \& Dallmann, W.K. 1996: Reactivation history of the long-lived Billefjorden Fault Zone in north central Spitsbergen, Svalbard. Geological Magazine 133, 63-84. https://doi.org/10.1017/S0016756800007251.

McClay, K.R., Dooley, T., Whitehouse, P. \& Mills, M. 2002: 4-D evolution of rift systems: Insights from scaled physical models. American Association of Petroleum Geologists Bulletin 86, 935-959.

Müller, R.D., Seton, M., Zahirovic, S., Williams, S.E., Matthews, K.J., Wright, N.M., Shephard, G.E., Maloney, K.T., Barnett-Moore, N., Bower, D.J. \& Cannon, J.S. 2016: Ocean basin evolution and global-scale reorganization events since Pangea breakup. Annual Review of Earth and Planetary Science Letters 44, 107-138. https://doi.org/10.1146/annurev-earth-060115-012211.

Nielsen, E. 1941: Remarks on the map and the geology of Kronprins Christian Land. Meddelelser om Grønland 126, 1-35.

Peacock, D.C.P., Knipe, R.J. \& Sanderson, D.J. 2000: Glossary of normal faults. Journal of Structural Geology 22, 291-305. https://doi.org/10.1016/S0191-8141(00)80102-9.

Pedersen, S.A.S. 1988: Model of structural events in the Late Mesozoic platform break up between Greenland and Svalbard. Norsk Polarinstitut Rapport 46, 99-100.

Pedersen, S.A.S. 1989: Geological map of Kilen, Kronprins Christian Land, North Greenland, scale 1:100,000, (unpublished), In the archives of the Geological Survey of Denmark and Greenland. http://data.geus.dk/geusmapmore/get_binary_mapdb.jsp?digitalmap_ $\mathrm{id}=4313$ (accessed 10th of November 2016).

Pedersen, S.A.S. \& Håkansson, E. 1999: Kronprins Christian Land Orogeny Deformational Styles of the End Cretaceous Transpressional Mobile Belt in Eastern North Greenland. Polarforschung 69, 117-130.

Piepjohn, K. \& von Gosen, W. 2001: Polyphase deformation at the Harder Fjord Fault Zone (North Greenland). Geological Magazine 138, 407-434. https://doi.org/10.1017/S0016756801005660.

Piepjohn, K., von Gosen, W., Tessensohn, F., Reinhardt, L., McClelland, W.C., Dallmann, W.K., Gaedicke, C. \& Harrison, J.C. 2015: Tectonic map of the Ellesmerian and Eurekan deformation belts on Svalbard, North Greenland, and the Queen Elizabeth Islands (Canadian Arctic). Arktos 1, 12. https://doi.org/10.1007/s41063-015-0015-7.

Piepjohn, K., von Gosen, W. \& Tessensohn, F. 2016: The Eurekan deformation in the Arctic: an outline. Journal of the Geological Society 173, 1007-1024. https://doi.org/10.1144/jgs2016-081.

Safronova, P.A., Mattioni, L., Hautier, R., Moretti, I., Skinnemoen, Ø., Romanet, M., Marcy, F. \& Heskestad, B. 2015: Structural style and tectonic evolution of the northern part of the Bjørnøya Basin, South-Western Barents Sea, Norway. 77th European Association of Geoscientists \& Engineers Conference \& Exhibition, 1-4. 
Soper, N.J. \& Higgins, A.K. 1991: Late Cretaceous-Early Tertiary deformation, North Greenland. In Trettin, H.P. (ed.): Geology of the Innuitian Orogen and Arctic Platform of Canada and Greenland, Geological Survey of Canada, Geology of Canada, pp. 461-465.

Soper, N.J., Dawes, P.R. \& Higgins, A.K. 1982: Cretaceous-Tertiary magmatic and tectonic events in North Greenland and the history of adjacent ocean basins. In Dawes, P.R. \& Kerr, J.W. (eds.): Nares Strait and the drift of Greenland: a conflict in plate tectonics, Meddelelser om Grønland, Geoscience, Copenhagen, pp. 205-220.

Stemmerik, L. \& Håkansson, E. 1989: Stratigraphy and depositional history of the Upper Palaeozoic and Triassic sediments in the Wandel Sea Basin, central and eastern North Greenland. Rapport Grønlands Geologiske Undersøgelse 143, 21-45.

Stemmerik, L. \& Håkansson, E. 1991: Carboniferous and Permian history of the Wandel Sea Basin, North Greenland. Bulletin Grønlands Geologiske Undersøgelse 151, 141-151.

Stemmerik, L. \& Worsley, D. 2005: 30 years on - Arctic Upper Palaeozoic stratigraphy, depositional evolution and hydrocarbon prospectivity. Norwegian Journal of Geology 85, 151-168.

Stemmerik, L., Håkansson, E., Madsen, L., Nilsson, I., Piasecki, S., Pinard, S. \& Rasmussen, J.A. 1996: Stratigraphy and depositional evolution of the Upper Palaeozoic sedimentary succession in eastem Peary Land, North Greenland. Bulletin Grønlands Geologiske Undersøgelse 171, 45-71.

Stemmerik, L., Dalhoff, F., Lyck, J.M. \& Mathiesen, A. 1997: Oil geology and thermal history of eastern North Greenland. Geological Survey of Denmark and Greenland report 1997-49, 285 pp.

Stemmerik, L., Larsen, B.D. \& Dalhoff, F. 2000: Tectono-stratigraphic history of northern Amdrup Land, eastern North Greenland: implications for the northernmost East Greenland shelf. Geology of Greenland Survey Bulletin 187, 7-19.

Surlyk, F. 1991: Tectonostratigraphy of North Greenland. Bulletin Grønlands Geologiske Undersøgelse 47, 25-47.

Svennevig, K., Guarnieri, P. \& Stemmerik, L. 2015: From oblique photogrammetry to a 3D model - Structural modeling of Kilen, eastern North Greenland. Computers \& Geosciences 83, 120-126. https://doi.org/10.1016/j.cageo.2015.07.008.

Svennevig, K., Guarnieri, P. \& Stemmerik, L. 2016a: Tectonic inversion in the Wandel Sea Basin: a new structural model of Kilen (eastern North Greenland). Tectonics 35, 2896-2917. https://doi.org/10.1002/2016TC004152.

Svennevig, K., Alsen, P., Guarnieri, P., Hovikoski, J., Lauridsen, B.W., Pedersen, G.K., Nøhr-Hansen, H. \& Sheldon, E. 2016b: Descriptive text to the Geological map of Kilen, eastern North Greenland, scale 1:50,000, pp. 75-95. In Svennevig, K., Tectonic Evolution and 3D-modelling of eastern North Greenland - Structural geology of Kilen. PhD thesis, University of Copenhagen, Copenhagen, $114 \mathrm{pp}$.

Thórarinsson, S.B., Söderlund, U., Døssing, A., Holm, P.M., Ernst, R.E. \& Tegner, C. 2015: Rift magmatism on the Eurasia basin margin: $\mathrm{U}-\mathrm{Pb}$ baddeleyite ages of alkaline dyke swarms in North Greenland. Journal of the Geological Society 172, 721-726. https://doi.org/10.1144/jgs2015-049.

Zink-Jørgensen, K. 1994: The Trolle Land Fault System, Kim Fjelde, eastern Peary Land. In Håkansson, E. (ed.): Wandel Sea Basin: Basin Analysis, University of Copenhagen, Copenhagen.

Zink-Jørgensen, K. \& Håkansson, E. 1994: Geological Map of the Kim Fjelde Area, eastern Pear Land, North Greenland. In Håkansson, E. (ed.): Wandel Sea Basin: Basin Analysis, University of Copenhagen, Copenhagen. 